\title{
THE CLASSIFICATION AND CHARACTERISTICS OF CONTROL CHARTS
}

\author{
Izabela Dagmara Czabak-Górska ${ }^{1}$
}

\begin{abstract}
Control Charts are the basic tool for quality control. They were developed in the 1920s when the dominant type of production was mass production. In order to properly use classic Control Charts, the data from the manufacturing process should meet the following assumptions: an empirical distribution of measurement data should be normally distributed or close to a normal distribution, measurement data should be independent, the manufacturing process should be capable of quality depending on the type of Control Chart, a sample that is large enough (sometimes made of several elements) must be taken. Currently, a shift can be observed from mass production towards short production runs, which causes the proper use of the traditional approach to be impossible. In recent years, control charts are once again in the spotlight, and consequently many scientists, i.e. Reynolds, Zimmer, Costa, Calvin and Chan have undertaken the task to adapt the classic idea of keeping Control Charts to modern conditions of production. The development of science in this area allows for the avoidance of making major mistakes in the conduct of Control Charts and for making the wrong decisions based on erroneous analysis. However, the appearance of new literature pieces implies the need to classify Control Charts, therefore, this article describes the idea of conduct, the most important assumptions and distribution of classical Shewhart's Control Charts, as well as a suggestion for the distribution of advanced Control Charts that meet the needs of the currently used production types. The work also contains a concise description of the chosen control charts as well as the threats resulting from their inappropriate selection. This elaboration is an extension to the article of Czabak-Górska (2017).
\end{abstract}

UDC Classification: 338.3; DOI: http://dx.doi.org/10.12955/cbup.v5.907

Keywords: SPC, the classification of control charts, Shewhart's charts, charts of the new generation, sequential charts, standardized charts, adaptive charts, special charts

\section{Introduction}

Control Charts are the basic tool for quality control which was developed in the 1920s when the dominant type of production was mass production. Increased quality awareness and technological progress are driving companies to introduce and modify existing solutions and methods to monitor and control production processes. In addition, intense global competition and the need to meet the needs of the customer who increasingly focus their attention on high quality at low prices are the main reasons for changing the type of production. Increasingly, mass production is moving away from series production, piece production or make-to-order production. Consequently, it leads to differentiation of production. These types of actions also cause the processes to become more and more complex, so it turns out that some of the assumptions from the 20 s are not met by processes. This results in the fact that some of the classic SPC tools cannot be properly used in practice. Many scientists, such as Reynolds, Zimmer, Costa, Calvin, and Chan, have adapted the classic idea of Control Charts to the modern conditions of production. The aim of the paper is a literature review of the modification of classic Control Charts and special Control Charts developed to enable them to be used for monitoring and controlling production processes when the normality and autocorrelation of process measurement assumptions is not fulfilled.

\section{A brief review of literature}

The main purpose of a manufacturing process is to produce a product with the support of, among others, quality control whose main task is to extract and reject non-conforming units which do not meet certain criteria (requirements). To make the identification of these units profitable a preventive strategy should be undertaken that disables the production of useless products, and consequently protects the company against unnecessary financial as well as temporal losses. For this purpose, among all Control Charts an essential tool in Statistical Process Control (SPC) are used and are based on graphical and statistical analysis. According to Greber (1999) the idea of Control Charts is monitoring and controlling the process in real time (i.e. on-line control), which allows for systematic observation of the controlled process. Yen, Hong \& Ha (2013) write that they enable, in a relatively easy way to distinguish common causes from special causes.Then, the person supervising the manufacturing process may, on the basis of the controlled product characteristics, track its progress and evaluate whether the variations of the statistical measure (chose on the basis of the type of

\footnotetext{
${ }^{1}$ Opole University of Technology,i.czabak-gorska@ po.opole.pl
} 
conducted Control Chart e.g. average, standard deviation) of the controlled features are so significant that they indicate deregulation of the process.

The efficacy of the use of this tool is mainly based on the proper selection of a chart and its adjustment to the characteristics and course of the processes (also taking into account the economic conditions), from the most common ones (e.g. specific for mass production) to processes which are non-standard (e.g. unit or multi-series production). Scientific research carried out in enterprises, as well as the author's own experience show that the misuse of Control Charts leads to serious errors in their conduct. According to the research conducted by Kowalczyk (2012), the first primary problem results from the use of specifications to determine the limits of intervention in the manufacturing process, which will only contribute to process control without the possibility of its improvement. In this situation, Control Charts are treated as a kind of "lifebelt," which will be used in case of reclamations. Analysis of key characteristics of the use of Control Charts only in the case of "emergency" situations as documentation of the correct process. Kowalczyk (2012) also stated that the next mistake is trivializing the role of the manufacturing employee, whose task is to conduct Control Charts without any substantive preparation (an employee receives specific guidelines which he must follow, without the possibility to make any decisions, e.g. on stopping the process or signaling the need to introduce corrective actions). In these types of situations, SPC comes down to a rigid indication of relevant statistics and creating documentation, which eventually turns out to be useless.

Classic Control Charts were introduced in the 1920s, when the dominant model was mass and multiseries production. Constantly progressive economic and social transformations, globalization and the unification of the market, as well as technological development, in a natural manner changed the type of production in enterprises. As a result, it appears that traditional SPC tools (including Shewhart's Charts), due to certain assumptions cannot be practically used in an appropriate manner.

Increasingly, a trend can be observed of companies undertaking production of small batches and in short production runs (which is particularly evident in micro and small enterprises). Multi-assortment production and short production runs are very often associated with frequent retooling of machines within one manufacturing process. This in turn leads to a situation where there is no possibility (also due to lack of a sufficient amount of time) of obtaining a sufficiently large sample to determine the stability of the manufacturing process. Kujawińska \& Więcek-Janka (2010) emphasize that a large amount of various types and configurations of the manufactured products lead to the establishment of an "infinite" number of control charts each time there is a change in the assortment. In addition, studies of real production processes carried out by Kujawińska \& Więcek-Janka (2010) and Boypati, Nasiru \& Lakshmi (2015) indicate that the assumption of a normal distribution of the measurement data is not always respected. Kujawińska \& Więcek-Janka (2010) proved that the use of Shewhart's Charts in this type of situations can lead to, among others, the appearance of false alarms indicating process deregulation, failure to detect special causes or deterioration of the course of the process.

Due to the situations mentioned above, a number of theses have appeared related to the new Control Charts for example Boypati, Nasiru \& Lakshmi (2015), Ali, Pievatolo \& Göb (2016), Mohammed, Panesar, Laney \& Wilson (2013), which have been adjusted to specific situations which occur in the manufacturing process. Therefore, there is a real need to elaborate their classification. The aim of this article is to update the division of the selected Control Charts and prepare their concise description, which takes into account the most recent scientific findings and market trends.

\section{Classic control charts of Shewhart}

Dahlgaard, Kristensen \& Kanji (2000) indicate that the first Control Charts were developed in 1924 by W. A. Shewhart, in order to determine the boundaries in which a manufacturing process should be held (i.e. variation control). As is well known, no production process proceeds in a perfectly stable manner, due to the existing, previously mentioned, common and special cause, whose definitions, in accordance with ISO 3534-2 (2010) standard, are as follows:

- common cause - "factors typically existing in large numbers, where each of them is of relatively little importance, leading to variability, which must necessarily be identified",

- special cause - "factors (usually systematical), which can be detected and identified as those causing qualitative property changes or changes in the level of the process". 
Hamrol (2009) underlines that, in case of using Shewhart's Control Charts, it is important to preserve the assumption of the normal distribution of the measurement data or being as close to normal distribution as possible, which means that the process is statistically regulated. Failure of meeting this assumption determines the need to apply a different type of Control Chart, due to the emerging risks which will be described in the next chapter.

To verify whether the distribution of the measured data is normal or close to normal, a so-called pilot sample should be carried for at least 100 observations (these data are usually read from a Check Sheet). Then, based on a histogram or an appropriate statistical test, a verification of the assumption of normal distribution occurs. Next, an assessment of the process's capability is carried out, which, depending on the branch should be maintained at the level of $c_{p} \geq 1,33 \vee\left(c_{p} \geq 1,66\right)$.

If the above assumptions are met, an appropriate Control Chart should be chosen, taking into account the kind of studied feature/product characteristic (measurable or unmeasurable), as well as the size of the taken samples which are usually determined by economic reasons (Fig. 1).

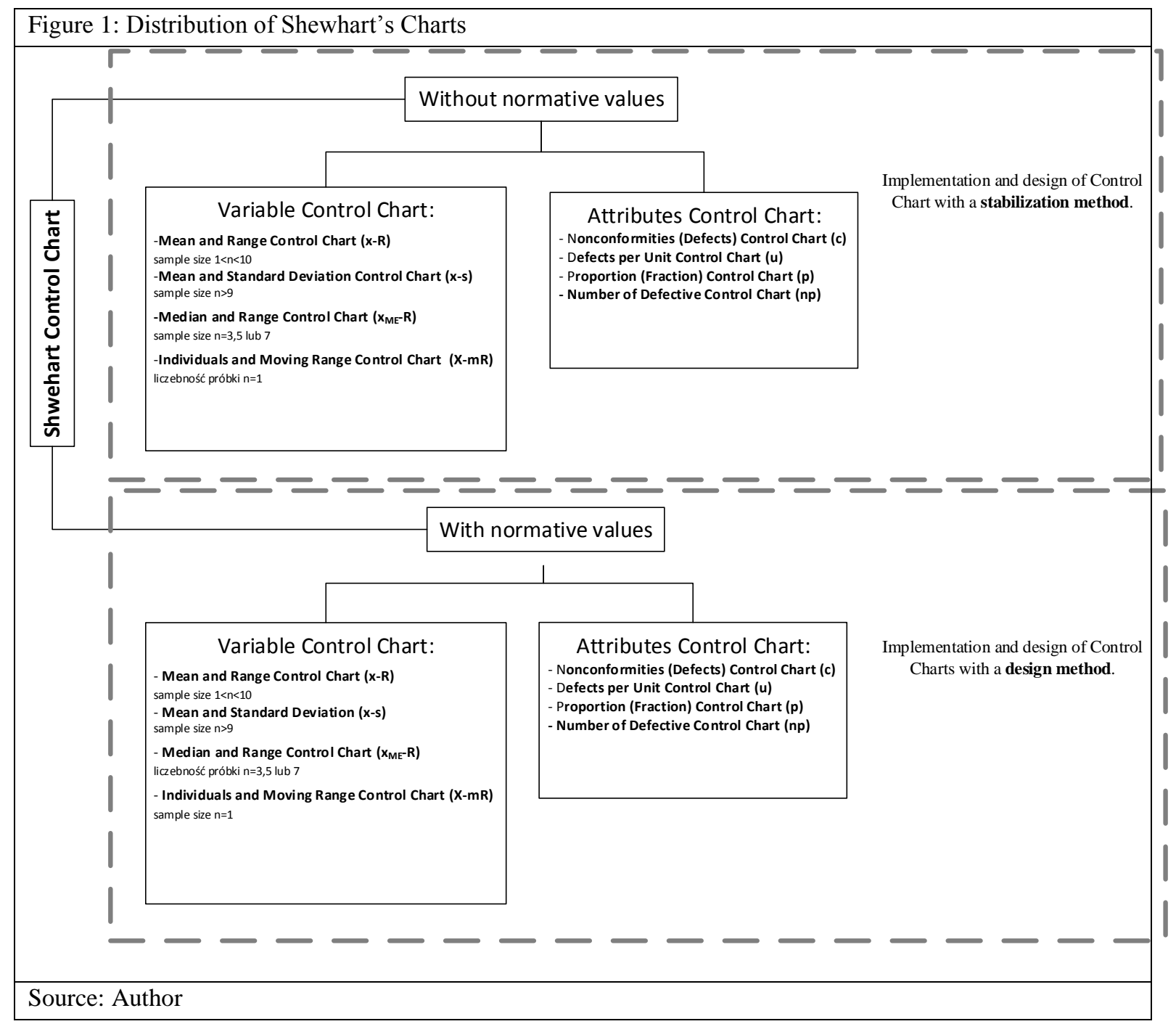

The above division determines two methods of implementation and design of Control Charts - design and stabilization. Kowalczyk (2012) writes that the first of them concerns the charts with pre-defined normative values, thanks to which it is possible to check whether the tested feature is significantly different from the specified normative values, with values greater than expected (it is assumed that the production process is affected by a special cause). On the other hand, according to Kowalczyk (2012), the stabilization method is based on the determination whether the studied measurements differ between each other by a value greater than that which should only be attributed only to random disturbance. 
When conducting Control Charts, the abilities to read the stability of the process and interpret graphs are equally important. In general, when monitoring the process with the use of Control Charts, it is expected that subsequent points on the graphs will be arranged symmetrically around the center line. In addition, the ISO 8258+AC1 standard (1996) describes 8 situations that may indicate process deregulation, they are the so-called process configuration tests:

- one point outside zone A,

- fifteen points in zone $\mathrm{C}$ above or below the center line,

- nine subsequent points in zone $\mathrm{C}$ or beyond it on the same side of the center line,

- six consecutive points constantly increasing or decreasing,

- fourteen points subsequently alternately increasing and decreasing,

- two of three consecutive points in zone A or outside it,

- four out of five consecutive points in zone B or beyond it,

- eight subsequent points on both sides of the center line, but none in zone C.

Olszewska (2008) emphasizes that the above-mentioned configurations do not determine a one hundred percent deregulation of the process. They only constitute information about any worrying symptoms of deregulation.

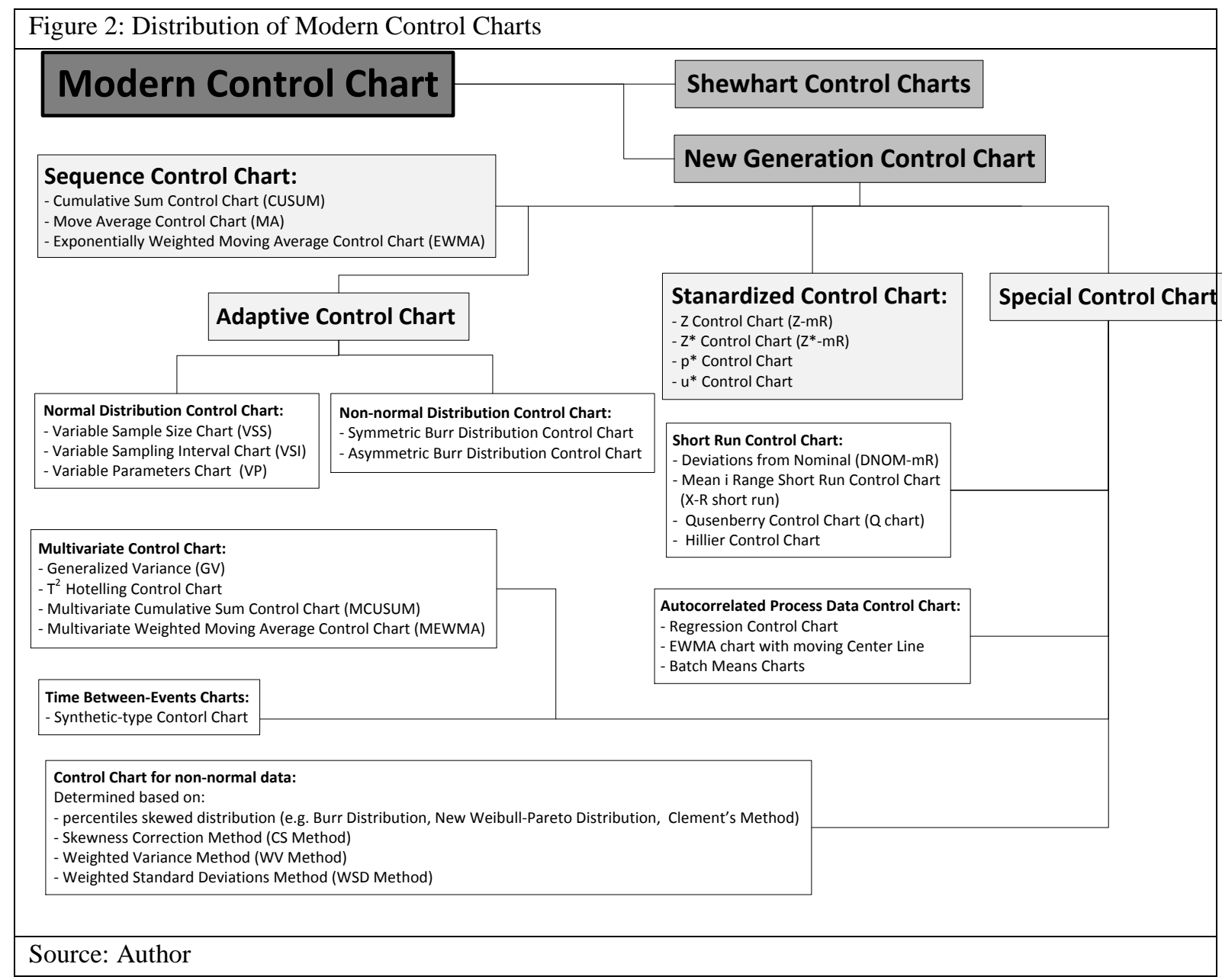

\section{Modern Control Charts}

The author presents a suggestion for the division of Control Charts, meeting the needs of the twentyfirst century, and defines them as Modern Control Charts (Fig. 2). Two main categories of Modern Control Charts have been distinguished: Shewhart's classic ones (this type of chart persists to be used in the industry) and the new generation (Olszewska (2008) defines it as an alternative to Shewhart's Control Charts in the case where no assumption listed in the previous section is met, as well as one identifying even small results of special interferences much faster). In turn, the charts of the new 
generation are grouped into four subcategories: Sequential, Adaptive, Standardized and Special (the distribution of Shewhart's Charts is in accordance with Fig. 1).

According to Bartkowiak (2011), Sequential Charts prove greater sensitivity to the variability of the process in comparison to Shewhart's Control Charts and are used to detect emerging trends and small shifts in the average value of the production process. Mondgomery (2009) notes that Shewhart's Control Charts use information about the process originating from the last observation of a sample and ignores all the information provided by a whole sequence of points, which, in turn, causes them to become less sensitive to small changes, e.g. technological ones. Among sequential charts, the following can be distinguished: Cumulative Sum Control Chart (CUSUM), Move Average (MA) and Exponentially Weighted Moving Average (EWMA). Their descriptions and application examples have been described, for example, by Sałaciński (2009).

Olszewska (2008) indicates that Adaptive Charts constitute an alternative to Sequential Control Charts, as they are also very sensitive to small changes in the process. Generally, the design and operation of Control Charts requires the determination of three parameters: sample frequency, sample size, coefficient for control limits (it determines the distance of the lower and upper tolerance limit from the Center Line respectively and is expressed in the number of standard deviations). According to Psarakis (2015), a Control Chart is considered to be adaptive if at least one of the parameters can be changed in real time depending on the position of the observation of the previous samples with respect to Control Limits. Psarakis (2015) notes that Adaptive Control Charts are more efficient than Shewhart's Charts, as they use archived data to determine the future scheme of the process. Psarakis (2015) described the rules for process control with the use of Adaptive Control Charts, according to which if the current measurement is too far from the Center Line, there is a suspicion of displacement of the process. Otherwise, it can be concluded that the process runs properly. Therefore, if the measurement is within the Control Limits and at the same time close to them, it is reasonable to increase the sample size while at the same time reducing the sampling frequency. Whereas, in a situation in which the measurement is close to the Center Line, it is possible to reduce the size of the sample while increasing the sampling frequency. The principle of extracting Control Limits both for a normal distribution (e.g. Variable Sample Size chart - VSS, Variable Sampling Interval chart - VSI, Variable Parameters chart - VP) as well as for other than normal (e.g. symmetric and asymmetric Burr's Charts) has been described, e.g. by Olszewska (2008).

Kowalczyk (2012) indicates that the Standardized Charts have use in the case of production characterized by short series. They are versatile in application and do not require practically any prior assumptions. Exemplary Standardized Charts are the $\mathrm{Z}$ and $\mathrm{Z}^{*}$ Chart (both are most often conducted with a moving range of $\mathrm{mR}$ ), $\mathrm{u}^{*}$ and $\mathrm{p}^{*}$. Oakland (2004) suggests using a $\mathrm{Z}$ or $\mathrm{Z}^{*}$ Chart in a situation in which the numerical values of tolerance significantly differ from product to product. Kowalczyk (2012) indicates that this type of charts is perfect for the analysis of products with different parameters on a single chart.

In turn, Special Charts were divided into: Short Series, Multivariate, for monitoring the Time Between Events, distributions other than normal and for autocorrelated data. Boyapati, Nasiru \& Lakshmi (2015) note in the case of short production runs, data for determining Control Limits is usually lacking, because the process is completed before they are estimated, leading to a situation in which stability assessment occurs afterwards. Boyapati, Nasiru \& Lakshmi (2015) also indicate that in cases when it is possible to collect the appropriate amount of data, it is followed by conversion of machines and changing assortment, which is connected to the establishment of a new chart. In these types of situations, charts like Deviations from Nominal (DNOM-mR), Mean and Range Short Run Control Chart (X-R short run), Qusenberry (Q chart) or Hiller are well suited. A way of determining Control Limits has been described by Qusenberry (1991) and Hiller (1967, 1969) respectively. It turns out, however, that these charts are by far the least frequently used in manufacturing enterprises, though they are constructed on the basis of a few preliminary measurements. Kujawińska \& Więcek-Janka (2010) indicate that the DNOM Chart is used for a situation when the process variability with respect to specific series is identical (which is subject to additional verification). The way of determining Control Limits for these type of control charts has been described, for example, by Montgomery (2009). 
In their studies, Ali, Pievatolo \& Göb (2016) indicate that in order to control high-quality manufacturing processes, which require a very low level of defectiveness (expressed mostly in pieces per million produced) characteristic to automatic production (i.e. arms systems, integrated circuits) the so-called Between Time-Events Charts (TBE Charts) are to be used. Instead of controlling the number of events occurring in a specific sample interval, TBE graphs monitor the time between the occurrences of events. According to Yen, \& Chong Ha (2013) the term "event" refers to the appearance of incompatible components in the manufacturing process, e.g. failures in reliability analysis, accidents, arrival of client, etc. whereas, the "time" refers to other variables (both discrete and continuous) monitoring the number of observations between subsequent events. These are the socalled Synthetic-Type Control Charts. Examples of their use have been described, e.g. by Yen, Vhong, Ha (2013) or Ali, Pievatolo, Göb (2016).

There are many situations in which simultaneous monitoring and control of two or more associated qualitative features/characteristics is necessary, and their independent control may prove to be misleading. According to Montgomery (2009), this is caused by the fact that both the error of the I type (recognizing that the process is dysregulated in the case of its stability) as well as the probability of the occurrence of an observation in Control Limits are not the same as in the case of a one-factor chart. The answer to this type of need is constituted by Multivariate Control Charts i.e. Generalized Variance Control Chart (GV Control Chart), T2 Hotelling Control Chart, Cumulative Cum for Individual Observations (MCUSUM) and Mean Values (MEWMA). Their description can be found e.g. in the work of Montogomery (2009).

The most commonly occurring distributions of measurement data, apart from normal distribution, are skew distributions. For inclined populations, Karagöz and Hamurkaroglu (2012), indicate the risk of the occurrence of a false alarm increases along with the value of the $\mathrm{k}_{3}$ asymmetry index, the reason is the discrepancy in the variation of the normal and asymmetric distribution. In literature, a number of heuristic methods can be found used to indicate the Control Limits in the case of distributions other than normal (including skewed), with the use, for the example, of skewed distribution percentiles, the Skewness Correction Method (SC Method), the Weighted Variance Method (WV Method) or the Weighted Standard Deviations Method (WSD Method). The idea of determining the Control Limits for this type of charts has been described by for example Karagöz and Hamurkaroglu (2012) as well as Czabak-Górska (2016).

Magaji, Yahaya, \& Asiribo (2015) point to the fact that in the case of continuous processes, the assumption of measurement data independence is not always assured, in particular when subsequent units are similar to each other. They also point out that along with the increased dependence of data, the probability of the occurrence of false signals on the Control Chart increases. Karaoglan \& Bayhan (2011) suggest three possible approaches to the control of correlated data:

- modification of data using the Autoregressive Integrated Moving Average model (ARIMA) and classic Shewhart's Charts,

- the adjustment of standard control limits in conventional Control Charts to account for autocorrelations resulting from the observation of the process,

- eliminating autocorrelation from the data with the use of Engineering Controllers.

Additionally, Keller (2011) suggests the use of dedicated charts i.e. Regression Control Chart, EWMA Chart with Moving Center Line, Batch Means Charts.

\section{Conclusion}

An accurate selection of Control Charts for a particular type of production and economic conditions constitutes an important element of monitoring and improving production processes. Ignoring the assumptions which constitute an integral whole with which a particular type of Control Chart may result in, inter alia, a situation where the stability assessment process is inadequate, which may in the end even result in its deregulation. A Control Chart which is improperly adjusted to the process may indicate false signals suggesting the appearance of special causes or in extreme cases even "mask" them, which may also lead to a shift in the process setup.

In the recent years, Control Charts have been booming again. Many scientists have undertaken the adaptation of the classic idea of conducting Control Charts to the modern production conditions, i.e. Ali, Pievatolo, Göb, Yen Chong Ha. Thanks to this, it is possible to avoid committing basic errors 
implying the formation of the above-mentioned situations. Modern Control Charts, i.e. Sequential, Adaptive, Standardized or those defined by the author as Special Charts can be much more effective than traditional Shewhart's Charts, but require a very good diagnosis of the process nature, ie. whether the distribution of the measured data is of a normal distribution character or other than a normal type of production, etc.

Changing the type of production of modern manufacturing enterprises (for meeting the expectations of customers) from mass production to small-series production leads to a lack of possibilities to take a sufficient sample (often multi-element) in order to conduct a pilot test which ultimately leads to the abandonment of the idea of process control using Control Charts. In such cases, assessment of stability usually occurs afterward, and the employees and management do not have the possibility to undertake appropriate steps at the right time, to prevent and eliminate the formation of errors. In turn, the inability to monitor processes using one Control Chart in the case of for example multi-assortment production causes great confusion and leads to the formation of useless documentation as well as entails huge costs and is completely unprofitable.

\section{References}

Ali, S., Pievatolo, A., \& Göb, R. (2016). An Overview of Control Charts for High- quality Processes. Quality and Reliability Engineering International, 32, 2171-2189.

Bartkowiak, M. (2011). Karty kontrolne obrazem zmienności procesu. Kwartalnik nauk o przedsiębiorstwie, 3(2011), 20, 63 71.

Boyapati, S. R., Nasiru, S., \& Lakshmi, K. N. V. (2015). Variable Control Charts Based on Percentiles of the New WeibullPareto Distribution. Pakistan Journal of Statistics and Operation Research, 11(4), 631-643.

Czabak-Górska, I. D. (2016). Karty kontrolne X i R dla rozkładów skośnych-studium przypadku. Zarządzanie Przedsiębiorstwem/Polskie Towarzystwo Zarzadzania Produkcja, (4), 10-17.

Czabak-Górska, I. D. (2017). Klasyfikacja nowoczesnych kart kontrolnych. Innowacje w Zarządzaniu i Inżynierii Produkcji, 2, $281-290$.

Dahlgaard, J. J., Kristensen, K., \& Kanji, G. K. (2000). Podstawy zarządzania jakościa. Warszawa: Wydawnictwo Naukowe PWN.

Greber, T. (1999). Jak czytać kart kontrolne Shewharta. Normalizacja, 11, 17-22.

Greber, T. (2000). Statystyczne sterowanie procesami-doskonalenie jakości z pakietem STATISTICA. Kraków: StatSoft Polska.

Hamrol, A. (2009). Zarzadzanie jakościa z przykładami. Warszawa: Wydawnictwo Naukowe PWN.

Hiller, F.S. (1969). X and R Chart Control Limits Based on a Small Number of Subgroups. Journal of Quality Technology, 1, 17-26.

Hillier, F. S. (1967). Small Sample Probability Limits for the Range Chart. Journal of the American Statistical Association, $62,1488-1493$

Karagöz, D., \& Hamurkaroglu C. (2012). Control charts for skewed distributions: Weibull, gamma, and lognormal. Metodoloski zvezki, 9(2), 95 - 106.

Karaoglan, A. D., \& Bayhan, G. M. (2011). Performance comparison of residual control charts for trend stationary first order autoregressive processes. Gazi University Journal of Science, 24(2), 329-339.

Keller, P. (2011). Statistical process control demystified. USA: McGraw Hill Professional.

Kowalczyk, A. (2012). „Ocena implementacji i skuteczności metod zarzadzania jakością w opinii dostawców branży motoryzacyjnej.”. Dissertation. Dissertation supervisor: prof. dr hab. A. Maleszka. Katedra Przyrodniczych Podstaw Jakości, Poznań.

Kujawińska, A., \& Więcek-Janka, E. (2010). Statystyczna ocena procesów w mikro i małych przedsiębiorstwach. Zeszyty Naukowe Uniwersytetu Szczecińskiego. Ekonomiczne Problemy Ustug [51 Uwarunkowania rynkowe rozwoju mikro i małych przedsiębiorstw Mikrofirma 2010], 431-439.

Magaji, A. A., Yahaya, A., \& Asiribo, O. E. (2015). Assessing the Effects of Autocorrelation on the Performance of Statistical Process Control Charts. International Journal of Mathematics and Statistics Invention, 3(6), 15-23.

Mohammed, M. A., Panesar, J. S., Laney, D. B., \& Wilson, R. (2013). Statistical process control charts for attribute data involving very large sample sizes: a review of problems and solutions. BMJ quality \& safety, bmjqs-2012, 362-368.

Montgomery, D. C. (2009). Introduction to statistical quality control. 6th Edition, USA: John Wiley \& Sons, Inc.

Oakland, J. S. (2004). Oakland on quality management. Oxford: Butterworth-Heinemann .

Olszewska, A. M. (2008). Karty kontrolne nowej generacji w zarządzaniu jakością produkcji. Dissertation, Warszawa: Oficyna Wydawnicza Politechniki Warszawskiej.

PN-ISO 3534-2 (2010). Statystyka. Statystyczne sterowanie jakościa. Terminologia i symbole. Warszawa: Polski Komitet Normalizacyjny.

PN-ISO 8258+AC1 (1996). Karty kontrolne Shewharta. Warszawa: Polski Komitet Normalizacyjny. 
Psarakis, S. (2015). Adaptive control charts: recent developments and extensions. Quality and Reliability Engineering International, 31(7), 1265-1280.

Quesenberry, C. P. (1991). SPC Q charts for a binomial parameter p: short or long runs. Journal of quality technology, 23(3), 239-246.

Quesenberry, C. P. (1991). SPC Q charts for start-up processes and short or long runs. Journal of quality technology, 23(3), 213-224.

Sałaciński, T. (2009). SPC statystyczne sterowanie procesami produkcji. Warszawa: Oficyna Wydawnicza Politechniki Warszawskiej.

Szkoda, J. (2004). Sterowanie jakościa procesów produkcyjnych: teoria i praktyka. Wydaw. Olsztyn: Wydawnictwo Uniwersytetu Warmińsko-Mazurskiego.

Yen, F. Y., Chong, K. M. B., \& Ha, L. M. (2013). Synthetic-type control charts for time-between-events monitoring. PloS one, 8(6), e65440, 1-13. 